Article

\title{
Epistemic Dependence and the EU Seal Ban Debate
}

\author{
Lars Christian Blichner \\ Department of Administration and Organization Theory, University of Bergen, 5007 Bergen, Norway; \\ E-Mail: lars.blichner@aorg.uib.no; Tel.: +47-55-58-21-75/78; Fax: +47-55-58-98-90
}

Submitted: 31 May 2014 | In Revised Form: 15 August 2014 | Accepted: 16 September 2014 |

Published: 31 March 2015

\begin{abstract}
On September 2009 the European Union (EU) adopted a regulation banning the import of seal products into the EU or placing seal products on the EU market. The European Parliament was the main driving force behind the regulation and the EU has been criticised by affected countries outside the EU for not basing this decision on the available expert knowledge. The questions asked are how, given epistemic dependence, non-experts may challenge an expert based policy proposal. Can non-experts hold experts accountable, and if so in what way? Three main tests and ten subtests of expert knowledge are proposed and these tests are then used to assess whether the European Parliament did in fact argue in a way consistent with available expert knowledge in amending the Commission proposal for a regulation.
\end{abstract}

\section{Keywords}

accountability; democracy; epistemic dependence; European Parliament; expert knowledge; globalisation; seal ban

\section{Issue}

This article is part of the special issue "The Role of Expert Knowledge in EU Executive Institutions", edited by Professor Åse Gornitzka (University of Oslo, Norway) and Dr. Cathrine Holst (University of Oslo, Norway).

(C) 2015 by the author; licensee Cogitatio (Lisbon, Portugal). This article is licensed under a Creative Commons Attribution 4.0 International License (CC BY).

\section{Introduction}

Political decisions are sometimes either made by experts or are based on expert knowledge. This gives rise to what may be called epistemic dependence (Hardwig, 1985). By epistemic dependence I refer to a situation where the reasons for making a particular decision in part or entirely are made with reference to knowledge the decision maker, someone else responsible for that decision or those affected by the decision, cannot or have difficulties in assessing. In the following the focus will be on political decisions made by politicians on behalf of others and affecting a third party. Typical cases include political decisions with a global reach. I will concentrate on one such decision; the European Union (EU) "regulation of the European Parliament (EP) and of the Council of 16 September 2009 on trade in seal products" (EP \& Council, 2009). This regulation has been criticised by representatives of countries outside the EU for being based on emotions and not facts.
What we have then is a political decision partly dependent on expert knowledge, that some claim was not made based on expert knowledge.

In a recent comment Canada's Fisheries Minister Gail Shea argued that the seal ban was based on emotions, and had "no basis in fact or in science". ${ }^{1}$ Other commentators have made similar statements critical of a ban, and a recent article concludes that in the European Parliament "arguments based on scientific investigations and expert evaluations were downplayed or not mentioned at all" and contrary to this "the Commission and Norway/Canada" based their arguments on scientific ground, they "spoke the same language" in the sense that "they agreed on what represented a valid and legitimate argument" (Wegge, 2013, p. 270). Thus at least part of this argument is that the Commis-

\footnotetext{
${ }^{1}$ Minister Gail Shea said this in relation to a WTO panel required by Canada to challenge the ban. According to her this would help take the emotion out of a ban. Palmer (2011, February 11).
} 
sion, together with the governments of Norway and Canada, "lost the case" ${ }^{2}$ because the case was not decided by science but by something else, be it issues of ethical identity linked to animal welfare, a strategic wish for re-election on the part of the EP members, or as argued by others and alluded to in the article; emotions. $^{3}$

The seal ban case is obviously complicated. As well as animal welfare issues, it involves legal issues, Inuit people's rights issues, and resource management issues, to name a few ${ }^{4}$. In a short paper like this there is a need to reduce this complexity. The point of departure is the observation that the amendments made by the EP in the European Parliament's Draft Regulation (Committee on the Internal Market and Consumer Protection [IMCO], 2009) differed substantially from the Commission proposal (European Commission [EC], 2008a) purportedly based on expert knowledge. The Commission proposal with these amendments made by the EP, by and large, later became the EU regulation on a ban. Moreover, as Wegge (2013, p. 270) states: "the lobbying strategies towards the Council did not matter much in the larger picture, as the Parliament was acknowledged by all to be the lead institution in this case". Thus, even if the regulation was adopted using the co-decision procedure, only the Parliament's arguments will be analyzed. The question is if the amendments made by the European Parliament, amendments that in essence later were reflected in the final regulation (EP \& Council, 2009), really were made without taking into account the expert knowledge available, as the critics claim? In relation to the Commission's exclusive right $^{5}$ to submit a legislative proposal, the Commission provides expert knowledge in support of EU decision-making (European Commission [EC], 2002). This means that the Commission, in submitting a proposal for a regulation, may issue an explanatory statement, often, as in the seal ban case, based on internal and external expert advice. The question asked is if the European Parliament took this expert knowledge into account or not when reaching a different conclusion than the Commission?

In order to arrive at a different result to those of the experts while still respecting expert knowledge, there will have to be a way for non-experts, in this case members of the European Parliament, to legitimately test the expert knowledge. Three main tests and ten subtests will be proposed as possible candidates. The

\footnotetext{
2 In the sense that the original Commission proposal was changed substantially to the effect of banning most products from commercial seal hunt from the EU market.

${ }^{3}$ For similar arguments see Perišin (2013, pp. 375, 395-396).

4 See for example Fitzgerald (2011), Howse and Langille (2012), Perišin (2013), Nielsen and Calle (2013) and Cambou (2013).

${ }^{5}$ With some exceptions.
}

general question then is if non-experts may realistically conduct such tests.

If the European Parliament actually did test the expert knowledge this should be revealed in the amendments made to the Commission proposal by the EP. Thus, the document that will be used to capture the European Parliament's view on the ban is the report delivered by the responsible committee in Parliament, the Committee on the Internal Market and Consumer Protection (IMCO, 2009) containing the "Draft European Parliament Legislative Resolution" concerning trade in seal products, the Commission proposal for a regulation, the opinions of the Committee on the Environment, Public Health and Food Safety (ENVI, 26.1.2009) and the Committee on Agriculture and Rural Development (AGRI, 18.2.2009), as well as the explanatory statements from the rapporteurs for the three committees. Thus in what follows IMCO (2009), containing these different documents, will be the main reference to the European Parliament's arguments. The emphasis will be on the amendments suggested by the different parliamentary committees and the justifications for these.

In a highly politicised and epistemically complicated case like the one discussed here, there may be reasonable disagreement on the issue of who the real experts are and as to what should be considered reliable knowledge. The point of reference in the following will be the knowledge provided by the Commission in the Commission's "Explanatory Memorandum" in the proposal for a regulation on a ban (EC, 2008a), an accompanying Commission Staff "Working Document" on the potential impact of a ban (EC, 2008b) and the two expert reports (European Food Safety Authority [EFSA], 2007; COWI, 2008) ordered by the Commission. The Commission formulated its proposal for a ban based on this. The Parliament reached a different conclusion to that of the Commission. The question is if the Parliaments conclusion is compatible with the expert knowledge that the Commission based its proposal on.

As indicated, this case is complicated as a host of different interests and goals were activated at different times in the decision making process (Sellheim, 2014). I will concentrate on the animal welfare aspects of the case that dominated both the expert reports and the discussion in Parliament (IMCO, 2009). The aim is limited to finding out if the Parliament used the expert knowledge made available by the Commission in amending the Commission proposal on issues linked to animal welfare, not the larger issue of whether the regulation as such was right, just or correct from the perspective of EU law, international trade regulations, resource management or the rights of indigenous peoples, to name some of the issues at stake in this case.

The expectation is that the Parliament, in amending the Commission proposal and arguing in favour of a stricter ban, in some way would take into account the 
expert knowledge provided by the Commission. Still, how can politicians, here considered non-experts, challenge a decision based on expert knowledge; that is, test whether the expert knowledge is correct, accurate, relevant, sufficient, consistent with the conclusions reached, and so on? Generally speaking, is it at all possible for non-experts to hold experts accountable, and if so in what way? Expert knowledge gives legitimacy to political decisions, but so does public opinion. When these two clash, as has apparently been the case when it comes to the seal products ban, one may expect legitimacy to be restored only by reconciling the two; either by a reconsideration of the expert knowledge involved or through a change in public opinion. I will concentrate on the former. The general question addressed then is whether or not the European Parliament was able to reconcile these two bases of legitimacy by way of the available expert knowledge. This will be done by considering if any of the ten tests developed (section three) were in fact conducted by the European Parliament (section four), but first a brief outline of the decision making process (section two).

\section{The Decision Making Process}

The political decision making process can, in brief, be described in five steps. ${ }^{6}$ First, the initiative leading up to a declaration on seal hunting in the European Parliament (European Parliament [EP], 2006) in September 2006 was based on pressure from civil society organisations and backed up by a large majority in the European Parliament. Second, the Commission accepted that this was a matter to be decided at the EU level with reference to the need for consistent legal rules throughout the common market. Some member states had already passed laws banning seal products and other member states had made plans to do so.

As indicated, the Commission ordered two separate expert investigations into the matter, one linked to animal welfare under the Directorate General for Environment, conducted by the European Food Safety Authority (EFSA, 2007), and another on the possible impacts of a ban conducted by external experts (COWI, 2008).

The result of this process was a proposal to ban the import and placing on the market of seal products throughout the EU, but with potentially wide ranging exceptions being made for seals that were killed without avoidable pain, what will be referred to as the Commission proposal (EC, 2008a). In practice this would mean that a large seal hunting country, such as Canada (as argued by the rapporteur for the responsible committee, Diana Wallis, in her "Explanatory Statement" criticising the Commission proposal)

${ }^{6}$ For a more comprehensive description of this process see Howse and Langille (2012), Wegge (2013) and Sellheim (2014)
(IMCO, 2009, p. 28), might well have been exempted from the ban. The proposal, according to the Commission, besides the formal objective of market harmonisation, had two "overarching objectives" that is; first, to "protect seals from acts that cause them avoidable pain, distress, fear, and other forms of suffering during the killing and skinning process", and second, "to address the concerns of the general public with regard to the killing and skinning of seals" (EC, 2008b, pp. 23, 51).

Third, on 5 March 2009 IMCO, as the responsible committee, issued its amendments to the Commission proposal for a ban. Four committees had been asked for opinions. As indicated, in the end, two committees (ENVI and AGRI) of four issued opinions to the responsible committee (IMCO). All three committees (IMCO, ENVI and AGRI) issued justificatory or explanatory statements and proposed concrete amendments to the Commission proposal (IMCO, 2009). ${ }^{7}$ As stated, the end result of these amendments to the Commission proposal for a ban was that the European Parliament recommended a much stricter ban.

Both at the second stage and this third stage was civil society actively involved. The animal welfare movement, but also those arguing against a ban had their say, and formal meetings with different stakeholders were conducted. These included indigenous peoples representatives and consultations involving experts from seal hunting nations like Norway and Canada. ${ }^{8}$

Fourth, the European Parliament adopted the regulation with a massive majority. The Council adopted the regulation with three countries abstaining (Wegge, 2013 , p. 268). The result was a total ban, but with an exception for indigenous people, showing that the lobbying had been effective in the sense that an exemption was made for hunting based on justifications linked to cultural survival. An exemption was even made for non-commercial resource management hunting, and for products carried into the European Union

\footnotetext{
7 In addition, the Committee on Legal Affairs later (1 April 2009), on its own initiative, issued an opinion on the legal basis of the proposed regulation.

${ }^{8}$ As stated by the Commission: "The stakeholders were invited to express their opinion on the completeness and reliability of the data presented in the draft report prepared by the EFSA working group, in order to avoid any possibility of leaving out some important scientific evidence. Moreover, the European Commission organised a workshop with experts from sealing countries, animal welfare non-governmental organisations as well as fur trade and hunters associations with the objective to receive feedback on the factual information under the country reporting exercise (national hunt management systems) conducted in the framework of the overall Commission assessment. Bilateral meetings were also held with a range of stakeholders, and took place at a political, as well as at a technical level." (EC, 2008a, p. 9, see also EC, 2008b, p. 12)
} 
that were bought elsewhere and were for private use only. The final EU regulation on principle followed the Commission proposal as amended by the European Parliament; a total ban with exemptions for indigenous peoples and non-commercial resource management hunting.

Fifth, the regulation was challenged in court both at the European level and the global level. At the European level the General Court concluded the regulation to be legal (European General Court [EGC], 2013) and the European Court of Justice subsequently denied an appeal (European Court of Justice [ECJ], 2013). At the global level the WTO Appellate Body, based on complaints from Norway and Canada, issued its report on May 22, 2014 (World Trade Organization [WTO], 2014). According to one interpretation, the Appellate Body found that "some aspects of the EU Seal Regime were discriminatory," but also that "the measure was provisionally justified under the public morals exception" (Howse, Langille, \& Sykes, 2014), in general meaning that the ban on products from commercial seal hunt is acceptable, while the exemptions made had not been fairly applied. Thus legally speaking, one may argue that the EU lost the case since the EU Seal Regime was deemed discriminatory (Fitzgerald, 2014). Howse et al. (2014) on the other hand argue that, "these concerns should be relatively easy for the EU to address". The practical result of this decision is most likely that the EU seal ban, at least in relation to large-scale commercial seal hunt, will continue. The media and many of those in favour of a ban, most notably animal rights organisations, have interpreted the decision as a (EU) victory, while many of those opposed to a ban, most notably representatives of indigenous communities, have criticised the decision. The Canadian Government, in a brief news release after the Appellate Body's decision, understandably was more reluctant to draw any firm conclusions, but relevant to this paper repeated that "The ban on seal products adopted in the European Union was a political decision that has no basis in fact or science" (Department of Foreign Affairs, Trade and Development Canada, 2014). No doubt the EU ban on seal products was a political decision, the question is if it really did not have any basis in fact or science?

\section{Epistemic Dependence and Politics}

Decisions made in a democracy may be more or less dependent on expert knowledge. What then decides the level of epistemic dependence? I suggest two dimensions, first the epistemic requirements in order to make a decision, and second, the epistemic transparency of a decision. By epistemic requirement I understand how much and varied expertise is needed in order to make a rational decision and the practical availability of this expertise. Generally speaking, the less expertise needed and the more available the ex- pertise, the less epistemic dependence. By epistemic transparency I mean the degree to which it is possible to validate the expert knowledge by non-experts (including the degree to which knowledge is openly accessible to everyone). Generally speaking the lower the level of transparency, the higher the level of epistemic dependence. Epistemic dependence then, when making a decision, is determined on the one hand by the level of expertise needed and if it is readily available, and on the other hand the possibility to confirm if the expert knowledge is correct and precise enough to be useful for a particular purpose. In the following I will concentrate on this latter practical epistemological aspect of epistemic dependence.

In a modern society there is typically a high degree of epistemic dependence not only when it comes to the relationship between experts and non-experts, but also among experts. This may be seen as a problem when it comes to democratic decision-making. According to Hardwig (1985) however, a person can make rational decisions based on information this person cannot personally validate. Moreover, a person who trusts his or her own instincts or conclusions over those of a trustworthy and competent expert is irrational. Hardwig's point is that people in a modern world, inside and outside science, to a large extent will have to trust established scientific results in order to have rational beliefs. Thus, applying Hardwig's "principle of testimony", "if $A$ has good reason to believe that $B$ has good reason to believe $p$, then $A$ has good reason to believe $p$ " (Hardwig, 1985, p. 336, 1991, p. 697), and A's believes are on principle rational even if $p$ occasionally may turn out to be wrong. If the opposite were to be true, that this makes $A$ irrational based on an individualist epistemology that says that you may only rationally believe what you yourself have proven true or right, most of modern science and most of people's believes in general will be irrational. That the number of dependencies, even among experts, only increases with the development of modern science adds to the complexities involved (e.g. If $A$ has good reason to believe that $B$ has good reason to believe that $C$ has good reason to believe that $D$ has good reason to believe (and so on) $p$; where B, C and D (and so on) are experts) (Hardwig, 1985, 1991).

This however does not necessarily mean that experts may always be trusted and that politicians and other citizens have no responsibility when it comes to evaluating experts and expert knowledge. A non-expert should have good reason to believe that an expert has good reason to believe something. The question is how a non-expert may establish a good reason to believe that an expert has good reason to believe something. Inspired by Hardwig's sceptical view (1985), but mainly indebted to Melissa Lane's $(2014)^{9}$ recent review of the

${ }^{9}$ Melissa Lane, in her comparisons of different views on how 
current literature on the subject I have tentatively established three general "tests" a concerned party may conduct; a first order quality test, a second order quality test, and a bias test. Based on these distinctions we may roughly specify at least ten subtests that may be conducted in order to try to substantiate or challenge the expert view (see Table 1). In the following a brief explanation of these tests are given and possible tentative examples relating to the ban on seal products in the EU are indicated.

Table 1. Three basic tests and ten subtests of expert knowledge.

\begin{tabular}{|c|c|c|}
\hline $\begin{array}{l}\text { First Order } \\
\text { Quality Tests }\end{array}$ & $\begin{array}{l}\text { Second Order } \\
\text { Quality Tests }\end{array}$ & Bias Tests \\
\hline $\begin{array}{l}\text { 1. Examining the } \\
\text { practical results } \\
\text { of expert } \\
\text { knowledge } \\
\text { 2. Examining the } \\
\text { content of expert } \\
\text { knowledge } \\
\text { 3. Examining the } \\
\text { evaluative } \\
\text { standard used by } \\
\text { the expert } \\
\text { 4. Communication } \\
\text { by experts of } \\
\text { expert knowledge }\end{array}$ & $\begin{array}{l}\text { 5. Expert } \\
\text { recognition } \\
\text { 6. Agreement } \\
\text { among experts }\end{array}$ & $\begin{array}{l}\text { 7. Bias linked to } \\
\text { relational norms } \\
\text { and values } \\
\text { 8. Bias linked to } \\
\text { material interests } \\
\text { 9. Psychological } \\
\text { bias } \\
\text { 10. Political bias }\end{array}$ \\
\hline
\end{tabular}

\subsection{First Order Quality Tests}

A first order quality test involves first an examination of the practical results of expert knowledge, second, an examination of the content of the knowledge, third an examination of the evaluative standards involved and fourth an examination of the expert's ability to communicate this knowledge in a way that makes it understandable to non-experts. It is a first order test because it aims at a more or less direct assessment of the quality of the knowledge involved. In the first subtest (1) one has to presume that even though the non-expert does not fully understand or may be totally ignorant about the epistemic base of a particular decision the practical results may be evaluated according to different standards. If the expert's predictions come true (or clearly do not) the epistemic dependence may in some instances be reduced to a level where trust is not any longer an issue.

(1) The EP found that the expert proposal does not work as intended.

In the second subtest (2) the presumption is that even

citizens may evaluate the claims of scientific experts, draws mainly on LaBarge (1997), Goldman (2001), Anderson (2011), and Brewer (1998). though the non-expert may not fully grasp the explanations given by the expert, the non-expert may never the less be able to reduce the level of epistemic dependence through investigating parts of the explanations involved, for example try to establish the level of uncertainty linked to the expert knowledge or more generally by assessing the relative accuracy of a particular field of expertise. Uncertainties are almost always present to some degree, but both the type of uncertainty and the level of uncertainty differ (Lane, 2014).

(2) The EP found that the expert proposal was based on irrelevant or too uncertain scientific evidence.

The third subtest (3) is based on the premise that expert knowledge involves an evaluative standard. This evaluative standard may be constitutive of the knowledge in question or it may be more contingent, as when the expert mandate establishes a particular evaluative standard and in the process determines to some degree what expert knowledge is relevant. In either case non-experts may question the relevance of the standard used relative to a particular political issue.

(3) The EP found the evaluative standard used by the experts wanting.

The fourth subtest (4) arguably linked to the first three subtests, presupposes that an expert is able to explain to others in a relatively clear and understandable way what knowledge they possess and in so doing is able to justify the relevance of this knowledge relative to the decision being made. A willingness and ability to do this in an understandable way will reduce epistemic dependence.

(4) The EP found that the expert opinion was unclear and difficult to understand and as a result the relevance of the expert knowledge was not appropriately justified.

In sum we may ask to what degree it is possible for a non-expert to even understand in any depth the premises of the conclusions reached by experts (Hardwig, 1985). This will differ from one type of expert knowledge to the next, but the premise in relation to the first order quality test is that some knowledge is better than no knowledge, and that the easier it is to understand the practical results, the logic behind expert knowledge, in addition to the standards of evaluation used, the less the epistemic dependence. After all, one reason why political scientists and others are preoccupied with how much knowledge people in general have on different politically relevant issues, for example climate change (Markowitz \& Shariff, 2012), is because they believe they can use this as an indication of a population's ability to understand and make up an 
opinion on an issue (Estlund, 2008, p. 260). In the seal ban case the claim has been made that people in general are not rational in making up their minds on the issue of seal hunt because they lack knowledge and hold false beliefs concerning how seal hunting is conducted (Perišin, 2013, p. 396).

\subsection{Second Order Quality Tests}

A second order quality test is based on the belief that there are reasons to trust that institutional structure; other experts and personal qualities of the experts may assure that expert knowledge is trustworthy. The fifth subtest (5) is premised on the belief in institutions (based on rules, ethical standards and sanctions) such as universities, expert commissions, peer-review, public track records and collegial credentials to produce trustworthy knowledge. It may also depend on personal traits such as proven trustworthiness. This should give the expert some unbiased credentials that the public may trust and thus reduce the problem of epistemic dependence.

(5) The EP challenged the experts with reference to their professional credentials.

The sixth subtest (6) is premised on the view that disagreement among experts makes epistemic dependencies more problematic, given it is impossible through a first order quality test or subtest five to decide who is most trustworthy. This does not mean that agreement implies that the expert knowledge is always correct, only that for non-experts not to trust such knowledge, without further qualification, is irrational.

(6) The EP referred to or engaged alternative experts with a different view than those engaged by the Commission.

Even the second order quality test is imperfect, but the general presumption is that the better the institutional safeguards when it comes to controlling expert knowledge in a society and the more there is agreement among experts, the less problematic is epistemic dependence.

The first order quality tests and the second order quality tests are positive in the sense that they aim at making sure the expert knowledge is correct. In addition to these two tests and independent of the results of these tests, an additional "negative" test should be conducted; a bias test. It is negative in the sense that it aims at discovering non-scientific reasons not to trust the expert knowledge under scrutiny.

\subsection{Bias Test}

A bias test involves trying to assess if expert advice is in some way affected by non-scientific or non-expert concerns. According to the seventh subtest (7) expert knowledge may be affected by relational ties as when colleagues or friends cover for each other, when arguments are not communicated in fear of embarrassment for some experts involved, concerns for the expert's reputation if proven that some results are incorrect, protection of one's colleagues, that the research has fallen victim to groupthink and so on. This test is notoriously difficult to conduct by non-experts.

(7) The EP argued that the experts involved in the process consisted of a group of people with relatively tight relational ties and with a common and positive view on seal hunting.

The eighth subtest (8) is more straightforward and involves possible material benefits the experts may gain from promoting certain results and subduing others (more or less consciously). There may be reason not to trust the information due to factors such as suspicion that the research is unduly interest driven, that it gives in to different external pressures or internal interests, like concerns for further research funding or work opportunities more generally. Even this confidence test is difficult to conduct; still sometimes such investigations at least may give reason for scepticism.

(8) The EP challenged the experts on the ground that they had previous economic ties with seal hunting and depended on this for their professional career, especially focusing on advice emerging from experts representing seal hunting nations.

The ninth subtest (9) is basically psychological and is linked to experimental findings that humans, including experts in their capacity as experts, tend to interpret the world differently dependent on factors such as changes in how information is presented, the circumstances under which the information is presented or some inbuilt preferences for some information rather than other. Such effect as the framing effect, wishful thinking, confirmation bias and others will generally increase the problem of epistemic dependence, but awareness of such biases and efforts to overcome them, for example through reframing, may to a degree at least partly compensate for this. ${ }^{10}$

(9) The EP argues that the expert opinion is unduly affected by the framing of the killing of seals as hunting and proposes a reframing emphasising the killing as slaughter.

Political bias, the tenth subtest (10), means that the work of experts may in some way be unduly affected

${ }^{10}$ For a review see Gowdy (2008). 
by the experts' personal political point of view, by power politics more generally or institutional epistemic doctrines bordering on the political.

(10) The EP would argue that the experts are tied to and dependent on a relatively small sector likely to colour their political view or that the expert proposal is based on too liberal a view of free trade and a political reading of the possible legal reactions to a more extensive ban.

\section{To What Extent Did the European Parliament Test the Expert Knowledge?}

The European Parliament reached a different conclusion than the Commission and the question is if these different conclusions are consistent with the facts as presented by the experts or in some way legitimately challenge these facts. Does the European Parliament argue in consequentialist terms and engage the scientific evidence? If not, if it all comes down to emotions, identity or strategic manoeuvrings, it would seem that the European Parliament is factually irrational. Is a more charitable interpretation possible? One that makes more sense of the fact that the EP rejected the positions of the Commission, Norway and Canada? Again, the question asked here is not what the correct decision should be, obviously people disagree on this, the question is if the EP presented arguments that in some way related to, took into account or criticised the expert knowledge relating to animal welfare? More concretely, the question is which of the ten tests, if any, the EP conducted?

\subsection{First Order Quality Tests}

In the seal ban case the Commission proposal was never implemented and the EP had no way of deciding if it actually worked or not; that is if it had resulted in less or no avoidable suffering for the seals and at the same time had satisfied the public. The EP then could not really conclude decisively on the first subtest. What the EP did however was to conduct an abstract test. They simply did not believe that the measures proposed by the experts would have the predicted effects. Even if we implement these measures the EP argued, seals will still suffer and people will not be satisfied. This did not mean that the EP rejected the expert view that it may be possible to kill seals without them suffering. The opinion of ENVI argued in the following way; "The question here is not whether seals can be killed humanely in theory but if they can be consistently killed humanely in the field environment in which seal hunt occur" (IMCO, 2009, p. 37). In the final regulation, the wording was as follows: "Although it might be possible to kill and skin seals in such a way as to avoid unnecessary pain, distress, fear or other forms of suffering, giv- en the conditions in which seal hunting occurs, consistent verification and control of hunters' compliance with animal welfare requirements is not feasible in practice or, at least, is very difficult to achieve in an effective way, as concluded by the European Food Safety Authority on 6 December 2007" (EP \& Council, 2009, p. 37).

In applying the second subtest the non-expert will look at the content of the expert's opinion and ask if the measures proposed in its name can be trusted to achieve the purpose of a political proposition. The expert knowledge used to justify a decision may be scrutinised by non-experts in order to, for example, decide the relevance and uncertainties of the expert knowledge. In the seal ban case, the responsible committee claimed "there is clear evidence that seals killed in commercial seal hunts consistently suffer pain, distress and other form[s] of suffering" (IMCO, 2009, p. 7). The Commission proposal at this point referred directly to the EFSA report in arguing "that it is possible to kill seals rapidly and effectively without causing them avoidable pain or distress, whilst also reporting that in practice, effective and humane killing does not always happen" (IMCO, 2009, p. 7). In the actual report EFSA in its conclusion writes, "There is strong evidence that, in practice, effective killing does not always occur..." (EFSA, 2007, p. 94). One may argue that the EP formulation gives the impression that every seal always suffers when killed, but it is also possible to interpret it to the effect that whenever seal hunt takes place a fair amount of the animals will in fact suffer. The problem here is that the facts as reported by the two expert reports are unclear and inconclusive. There is simply not enough research that has been done on the actual suffering of seals and the research that has been conducted suffers from various methodological deficiencies. Moreover, the different veterinary experts' opinions on the Canadian seal hunt, reviewed by the EFSA, disagree. The European Parliament, in order to substantiate its amendments to the Commission proposal empirically, may have referred to one or more of the more critical studies on Canadian seal hunt with citations from the EFSA report like: "existing regulations are neither respected or enforced" and commercial seal hunt "results in considerable and unacceptable suffering" (EFSA, 2007; p. 59, Burdon et al., 2001), or "there was widespread disregard for the Marin[e] Mammal Regulations by sealers" and "a minimum of $82 \%$ of shot seals were not killed by the first shot" (EFSA, 2007, p. 55; Butterworth, Gallego, Gregory, Harris, \& Soulsbury, 2007). The point here is not to argue that the EP formulation in some way was more accurate or correct than the formulation proposed by the Commission, only that both formulations arguably may be defended based on the expert knowledge provided by the EFSA report.

The responsible committee similarly argued that "humane killing methods cannot be effectively and 
consistently applied", that "effective monitoring" of seal hunting would be "impossible" and that "only a comprehensive ban...would meet the citizens' demands to see an end to the trade in seal products" (IMCO, 2009, p. 11). The first part of this argument is hard to substantiate by experts since no one can know what may or may not be possible in the future when it comes to seal hunting. On a charitable reading the European Parliament may be seen to argue that there are already comprehensive rules linked to seal hunting in Canada; there is enough evidence that these rules are not always followed in practice and that as a result seals do suffer. It would be unlikely therefore that better rules would give a much better result.

When it comes to the second part of the argument linked to the stated objective to convince the public that seal hunt is humanely conducted, this offers more empirical problems for experts and parliamentarians alike. The premise that the public actually wants a ban is open to discussion based on the expert studies. The COWI report covers this issue in some detail with reference to the public consultation procedure conducted by the Commission. People were asked to answer a questionnaire on a voluntary basis (questions only in English) and the consultation was placed on the net and was open for eight weeks (20.12.07-13.2.08).

73.153 persons from 160 different countries responded to the inquiry (COWI, 2008, p. 125), of these 32.061 from the EU member states (COWI, 2008, p. 129).

This of course is not a scientific study on the public attitude in the EU towards seal hunting, as clearly stated by COWI (2008, p. 124). However, the report continues to present the results in a way that may easily come across as scientific in form and concludes in its final recommendation to the Commission that "...it must be acknowledged that the public perception of seal hunting at large is against seal hunting for principal reasons..." (COWI, 2008, p. 136). If the public is seen as equated with the people answering the questionnaire, the European Parliament is probably right in arguing that the public will not be convinced by the Commission proposal. Of the respondent from the $27 \mathrm{EU}$ member states $72.5 \%$ "Do not accept hunt on principle" about the same percentage that are in favour of a strict ban (73.0\%) (COWI, 2008, p. 129). The Commission is more positive to the prospects of convincing the public through information campaigns. This conclusion is partly based on the fact that even people most interested in the issue of seal hunting (those that answered) are largely misinformed on the methods used to hunt seals. Again it is difficult to determine based on the expert knowledge provided who is right here, the Commission or the European Parliament. The main point is that part of the Parliament's justification may be reasonably defended with reference to the premises laid down in the COWI report and reported by the Commission as an indication of the public view (EC, 2008b, p. 11).
In addition, the EP may have argued more forceful$I y^{11}$, as the EU later argued in its first written submission to the WTO (European Union [EU], 2012, p. 24), that opinion polls in some EU countries showed that the public is opposed to a ban. These, opinion polls cannot however, while applying the same strict scientific criteria as those used by the EFSA, represent the entire population of the EU. Moreover, these opinion polls were mostly commissioned by IFAW, an organisation that, according to its own homepage, was "founded in 1969 to stop" the "cruel hunt for seals" (International Fund for Animal Welfare, [IFAW], n.d.). This does not necessarily imply a lack of trust in a market research company like Ipsos-MORI that in 2011 conducted a survey for IFAW on the seal ban. Even though this survey was conducted after the EU regulation was adopted, the survey may still be used to illustrate the difficulties involved in getting reliable and independent data on a highly politicised issue like the EU seal ban, in particular maybe when the clients have a vested interest in one particular result. Ipsos-MORI conducted a survey for IFAW including eleven EU countries. Five hundred interviews were made in each country. The survey found that the support for a ban was overwhelming with $56 \%$ answering that they "Strongly support" a ban. Prior to answering the question the respondents were read a statement, which according to Ipsos-MORI provided "respondents with some information on commercial seal hunting and the EU ban on the sale of seal products" (Ipsos-MORI, 2011, p. 1). Interestingly, in Great Britain half of the survey was conducted with the introductory statement and half without it. ${ }^{12}$ With the introductory statement $56 \%$ (the same as in all countries combined) were "strongly opposed" to a ban. Without the introduction this dropped to $46 \%$, while the "Neither/nor" or "Don't know/no opinion" options combined increased by $10 \%$. As suggested by subtest nine, this illustrates the well-known insight that the ways questions are framed heavily influence the answers you get. One may of course argue that those with better information were more sceptical to seal hunt, but then again, one has to decide if the information given in the introductory statement was sufficiently balanced.

In order to document the lack of knowledge in a certain field of inquiry one clearly needs experts as demonstrated in this case. Most of the experts' reports however concerned what is actually known and that would be relevant for the decision of a ban. This expertise was basically linked to the effectiveness of different killing methods and rules regulating seal hunt in different countries. The goal was to come up with best

\footnotetext{
11 This was argued by Rapporteur Frieda Brepoels in her justificatory statement for the ENVI (IMCO, 2009, p. 32).

12 The sample size in Great Britain was double of that in the other countries surveyed (1004 respondents).
} 
practices that could be used to establish a regulatory regime that could in turn be used by the EU to decide what hunting should be accepted and what not. This issue is intimately linked to subtest three.

Subtest three is about the evaluative standards used by the experts, whether these standards are inherent to the field of expertise or are linked to the mandate given to the experts by political authority. In the seal ban case the EP criticised the Commission for the mandate given to the experts and even the EFSA for its recommended method for killing seals humanely. In its justification the responsible committee wrote: "The Commission did not ask EFSA to assess whether commercial seal hunt is currently conducted in a humane fashion, but rather the most appropriate killing methods for seals to reduce as much as possible unnecessary pain, distress and suffering. The killing methods recommended in EFSA's report and the draft Regulation do not prescribe humane killing as any reputable veterinary authority would define it" (IMCO, 2009 , p. 8). Based on its findings (best practices) EFSA suggested establishing rules and regulations that as far as possible would relieve the seals of suffering. For the responsible committee however this was not enough. The committee went on to criticise not only the mandate, but also the criteria for what suffering should mean. It argues, "The concern of European citizens is about a trade involving suffering of wild animals, not only suffering which is avoidable. Unavoidable suffering may be very considerable." (IMCO, 2009, p. 8). This is also later linked to the second main objective; that of convincing the public that the regulation of a ban would improve the situation to their satisfaction. The responsible committee argues, "the removal of the word 'avoidable' is warranted since all the evidence indicates that EC citizens are concerned about the suffering caused by the hunting of seals, not only suffering which is avoidable" (IMCO, 2009, p. 11). The ENVI justified this in the following manner: "Unavoidable suffering may be very considerable given the term is not quantifiable" (IMCO, 2009, p. 38). Thus the committee refuted the evaluative standard used by the Commission and the experts alike and opted for a no suffering standard.

The result of this stricter standard, in addition to the results of the European Parliament's arguments in relation to the two first subtests, was that much of the references to the experts' knowledge or conclusions based on expert knowledge were deleted from the Commission proposal by the Parliament. Much of the expert knowledge provided by the Commission and the experts' reports, were deemed largely irrelevant.

Subtest four is about the way experts are able to communicate and thus justify the conclusions reached, to the non-expert. In this case there is no indication that the EP did not understand or more directly criticised the experts involved on this account.
The first order quality test then seems to have mixed results. What stands out is rather the lack of proper expert knowledge than the Parliament's lack of empirical references. The facts simply were not very clear. When it comes to consequentialist arguing relative to the first of the two "overarching objectives" for the ban (EC, 2008b, p. 7), the one linked to animal welfare, the Parliament may be seen to argue as convincingly as the Commission. The Commission argued that strict demands for detailed and enforceable rules for how to conduct seal hunt would give seal hunting nations an incentive to clean up their act. The Parliament came to the conclusion that the link between formal regulations and actual practice was hard to establish, and instead argued that a strict ban would lead to less hunting, and less hunting to less suffering. That the Parliament had a point is shown by the dramatic drop in the number and the price of landed seals in Newfoundland in the aftermath of the Parliament's 2006 initiative to establish a ban (Sellheim, 2014). As the final regulation for a ban states, "in order to restore consumer confidence....it is also necessary to take action to reduce the demand leading to marketing of seal products and, hence, the economic demand driving the commercial hunting of seals" (EP \& Council, 2009, p. 37).

\subsection{Second Order Quality Tests and Bias Tests}

The three parliamentary committees that participated directly in the discussions on the revision of the Commission proposal for a ban (IMCO, 2009) did not (as revealed by the documents) directly criticise or comment on either the credentials of the experts, disagreement among experts or at least three of the four bias tests proposed. The possible exception is subtest nine which relates to a critique that generally would claim that the experts or the experts' knowledge is in some way biased due to psychological factors that tend to influence experts' and non-experts' choices. Subtest nine is generally relevant in this case, as proponents of a ban have been criticised for basing their decision on emotions and not facts and with giving too much weight to the animal welfare issue relative to, for example, the effects of a ban on indigenous peoples (Cambou, 2013). The question I pose here however is if the Parliament, as revealed by the arguments presented in the IMCO report in some way criticised the expert knowledge for being biased in this way. The seal ban case may be framed in a number of ways, and the way the issue is framed may affect one's position. As indicated it may be framed as a legal issue, as an animal welfare issue, as a human welfare issue or as a resource management issue, an issue concerning the Arctic region or as a case of "public morals," to name the most obvious. ${ }^{13}$ The

${ }^{13}$ For a discussion on the many and changing goals linked to 
IMCO report touched on all of these aspects, but no doubt the animal welfare issue was the dominant one, and so it was for the experts. Both expert reports, and in particular EFSA's, were dominated by this concern. Still, the Parliament and the experts, as we have seen, framed the animal welfare issue differently. For the experts this was a question of making seals suffer as little as possible given that seal hunt should continue. For the dominant view in the Parliament it was a matter of the public perception of the hunt that led them to a standard of not making seals suffer at all and made amendments to the Commission proposal with the aim of possibly stopping seal hunt altogether. As indicated only such a strict standard would convince the public according to the majority in Parliament, and the public seems to have been understood as the people answering to the Commission's consultation questionnaire and summed up by COWI (2008).

Regarding the second order quality tests and the three remaining bias tests these were not used in the arguments presented in the IMCO report. Still, even these tests are interesting in the sense that the parliamentary committees may have used them, much in line with how these tests and the bias tests actually were used by the two expert reports. The expert reports (EFSA, 2007; COWI, 2008) based their findings on studies carried out by other experts, and it was the quality and possible bias of this research that was subject to the tests. First, as indicated, peer review was seen as a quality criterion, and most of the research subjected to scrutiny was not peer reviewed (subtest five). Second, the consulted experts disagreed substantially on the question of how much seals in practice suffer when hunted, if regulations are followed in practice and if the hunting may be seen as humane (subtest six). Third, it was argued that the people doing the research or the people providing the material for the research (e.g., videos of the seal hunt or reports by officially assigned inspectors of the hunt) could be biased due to interest linked to the outcome of the research (subtests seven and eight). Finally, since politics is not mentioned directly in the experts' reports it is not possible to conclude positively on subtest ten. Still, the issue of seal hunt is obviously highly politicised and the question as to the widely different interpretation of seal hunting practice and the questionable methods used leave the impression that at least organisational affiliation and politics in a wide sense may have influenced the research and that, whatever research is presented, a hidden political motive may be suspected (subtest ten). Together with the experts' methodological critique of the expert studies (subtest two) all this led to the conclusion by EFSA and COWI that the research on the effect of regulations on the practice of seal hunting was seriously flawed from the perspective

the seal ban case see Sellheim (2014). of the goal to get a scientifically valid and unbiased picture of how humane seal hunt in practice were conducted globally.

\section{Conclusion}

In many ways the decision of a ban may be seen as an example of how democratic decisions should be made. The decision was democratically initiated, thoroughly investigated by experts, civil society was actively involved all through the process, it was decided upon by a vast majority of a directly elected body (European Parliament), together with an indirectly elected body (Council) and finally accepted as legal inside the EU (General Court and European Court of Justice) and, at least provisionally, at the global level (WTO). Nevertheless, the regulation was criticised for not being based on the available expert knowledge. Can we conclude then that the European Parliament's justification for a strict ban was compatible with the expert knowledge available? The short answer is yes.

Surprisingly, after years of discussions over the seal hunt issue, expert knowledge is lacking on the most important questions linked to the Commission's two stated "main overarching objectives" (EC, 2008b, p. 7); we do not know the degree to which seals suffer when killed, or more to the point; the degree to which stricter regulations would help, and we do not know based on the expert reports, what attitudes EU citizens have regarding seal hunt. The European Parliament did not test the expert knowledge in the sense of criticising the expert findings, but the changes in the Commission proposal made by the Parliament and the justifications for these may, as argued, be as reasonably defended with reference to the available expert knowledge presented by the experts engaged by the Commission (EFSA and COWI) as the Commission proposal, the main problem for both the Commission and the Parliament being the lack of relevant and valid expert knowledge. The COWI report was particularly clear on this issue: "...the study cannot on the basis of empirical evidence document a possible correlation between legislation and practice", this correlation is rather an assumption based on the expectation that under a well functioning rule of law system people will follow the law (COWI, $2008,19-20)$. As argued by the EP, this general assumption may reasonably be doubted based on the evidence on Canadian seal hunt (as presented by the expert reports), when it comes to the specific issue of seal hunt.

So are Tenenbaum and Wildawsky (1984, p. 83) right that "data do not and cannot determine policy; rather, it is the policy perspectives of the participants that determine what data are important?" At least this case seems to confirm this thesis. One interpretation of the Commission proposal is that it started from the available data and presented a solution that could be backed up with those data. If accepted, 'the experts' 
perspective" would have prevailed. The European Parliament, on the other hand, started with a stated goal of no suffering based on public opinion and used the data to explain the necessity of a strict ban. In the end it was the Parliament's perspective that prevailed. There was little explicit disagreement on the facts or the lack thereof. The Parliament, as one might have expected from the critique levelled against it, did not cherry-pick data in order to make their case, but rather based it on the general results presented by the experts. The question still remains if more data could have moved the Parliament to reach a different conclusion? Possibly, with independent and scientifically valid detailed data on the public opinion showing an acceptance for sustainable seal hunt together with robust and unanimously accepted data showing that seals may be killed, in practice, without suffering. Another more basic question still in need of an answer is what perspective is most correct from a moral or ethical point of view, the experts' perspective or the European Parliament's?

\section{Acknowledgements}

Thanks to the editors for comments on an earlier draft.

\section{Conflict of Interests}

The author declares no conflict of interests.

\section{References}

Anderson, E. (2011). Democracy, public policy and lay assessments of scientific testimony. Episteme, 8, 144-164.

Brewer, S. (1998). Scientific expert testimony and intellectual due process. The Yale Law Journal, 107, 1535-1681.

Burdon, R. L., Gripper, J., Longair, J. A., Robinson, I., Ruehlmann, D., \& Fielder, J. (2001). Veterinary Report. Prince Edward Island, Canada: Commercial Seal Hunt.

Butterworth, A., Gallego, P., Gregory, N., Harris, S., \& Soulsbury, C. (2007). Welfare Aspects of the Canadian Seal Hunt: Preliminary Report and Final Report. Document submitted to EFSA. Retrieved from http: //www.harpseals.org/politics_and_propaganda/wel fareaspectsofcanadiansealhunt_butterworth.pdf

Cambou, D. (2013). The impact of the European ban on seal products on Inuit people a European concern. The Yearbook of Polar Law, 5, 389-415.

Committee on the Internal Market and Consumer Protection (IMCO). (2009). Report on the Proposal for a Regulation of the Parliament and of the Council Concerning Trade in Seal Products (A6-0118/2009). Brussels, Belgium: European Parliament.

COWI. (2008). Assessment of the Potential Impact of a
Ban of Products Derived from Seal Species. Brussels, Belgium: European Commission.

Department of Foreign Affairs, Trade and Development Canada. (2014). Harper Government Responds to WTO Decision on EU Ban on Seal Products. Department of Foreign Affairs, Trade and Development Canada. Retrieved from http://www.international .gc.ca/media/comm/news-communiques/2014/05/ 22b.aspx?lang=eng

Estlund, D. M. (2008). Democratic Authority: A Philosophical Framework. Princeton: Princeton University Press.

European Commission (EC). (2002). Communication from the Commission on the Collection and use of Expertise by the Commission: Principles and Guidelines, "Improving the knowledge base for better policies" (11.12.2002 COM(2002) 713 final). Brussels: European Commission.

European Commission (EC). (2008a). Proposal for a Regulation of the European Parliament and of the Council Concerning Trade in Seal Products (COM(2008) 469 final). Brussels, Belgium: European Commission.

European Commission (EC). (2008b). Commission Staff Working Document Accompanying Document to the Proposal for a Regulation of the European Parliament and of the Council Concerning Trade in Seal Products (Impact Assessment, SEC(2008) 2290/2). Brussels, Belgium: European Commission.

European Court of Justice (ECJ). (2013). Judgment of the European Court of Justice (Grand Chamber), Appeal - Regulation (EC) No 1007/2009 - Trade in seal products - Restrictions on importing and marketing such products - Action for annulment - Admissibility - Right of natural or legal persons to institute proceedings - Fourth paragraph of Article 263 TFEU - Concept of 'regulatory act' - Legislative act - Fundamental right to effective judicial protection. Luxembourg: European Court of Justice.

European Food Safety Authority (EFSA). (2007). Scientific Opinion of the Panel on Animal Health and Welfare on a Request from the Commission on the Animal Welfare Aspects of the Killing and Skinning of Seals. Parma, Italy: European Food Safety Authority.

European General Court (EGC). (2013). Judgment of the General Court (Seventh chamber), 25 April 2013. Trade in Seal Products: Regulation (EC) No 1007/ 2009. Brussels, Belgium: European General Court.

European Parliament (EP). (2006). Declaration P6TA(2006)0369. Banning Seal Products in the European Union. Brussels, Belgium: European Parliament.

European Parliament (EP), \& Council (2009). Regulation (EC) No 1007/2009 of the European Parliament and of the Council of 16 September 2009 on trade in seal products, L 286/36. Official Journal of the European Union. Brussels, Belgium: EP/Council.

European Union (EU). (2012). European Communities- 
Measures Prohibiting the Importation and Marketing of Seal Products. Brussels, Belgium: European Union.

Fitzgerald, P. L. (2011). "Morality" may not be enough to justify the EU seal products ban: Animal welfare meets international trade law. Journal of International Wildlife Law \& Policy, 14, 85-136.

Fitzgerald, P. L. (2014). The WTO, seal-hunting, and public morality. Animal Law Committee Newsletter, Summer, American Bar Association.

Goldman, A. I. (2001). Experts: which ones should you trust? Philosophy and Phenomenological Research, 63(1), 85-110.

Gowdy, J. M. (2008). Behavioural economics and climate change policy. Journal of Behaviour and Organization, 68, 632-644.

Hardwig, J. (1985). Epistemic dependence. The Journal of Philosophy, 82(7), 335-349.

Hardwig, J. (1991). The role of trust in knowledge. The Journal of Philosophy, 88(12), 693-708.

Howse, R., \& Langille, J. (2012). Permitting pluralism: The seal products dispute and why the WTO should permit trade restrictions justified by noninstrumental moral values. Yale Journal of International Law, 37, 366-432.

Howse, R., Langille, J., \& Sykes, K. (2014). Sealing the deal: Animal welfare, public morals and trade: The WTO panel report in EC-Seal products. American Society of International Law Insights, 18(2). Retrieved from http://www.asil.org/insights/volume/ 18/issue/12/sealing-deal-wto's-appellate-bodyreport-ec---seal-products

International Fund for Animal Welfare (IFAW). (n.d.). Saving seals section. International Fund for Animal Welfare. Retrieved from http://www.ifaw.org/ international/our-work/seals/ending-canadas-cruel -commercial-hunt

Ipsos-MORI. (2011). Ban on sale of seal products-Poll of $11 \mathrm{EU}$ countries, topline results. Retrieved from
https://www.ipsos-mori.com/Assets/Docs/ipsosmori-seal-hunting-2011-topline.pdf

LaBarge, S. (1997). Socrates and the Recognition of Experts. In M. L. McPherran (Ed.), Wisdom, Ignorance, and Virtue: New Essays in Socratic Studies (pp. 5162). Edmonton: Academic Printing and Publishing.

Lane, M. (2014). When the experts are uncertain: Scientific knowledge and the ethics of democratic judgement. Episteme, 11, 97-118.

Markowitz, E. M., \& Shariff, A. F. (2012). Climate change and moral judgement. Nature Climate Change, 2, 243-247.

Nielsen, L., \& Calle, M.-A. (2013). Systematic implications of the EU-seal products case. Asian Journal of WTO \& International Health Law and Policy, 8, 41-75.

Palmer, R. (2011, February 11). Canada seeks WTO review of EU ban on seal products. Reuters. Retrieved from: http://uk.reuters.com/article/2011/02/11/usseals-idUKTRE71A3AV20110211

Perišin, T. (2013). Is the seal products regulation a sealed deal? EU and WTO challenges. International and Comparative Law Quarterly, 62(2), 373-405.

Sellheim, N. (2014). The goals of the EU seal products trade regulation: From effectiveness to consequence. Polar Record, in press.

Tenenbaum, E., \& Wildawsky, A. (1984). Why politics control data and data cannot determine politics. Scandinavian Journal of Management Studies, November, 83-100.

Wegge, N. (2013). Politics between science, law and sentiments: Explaining the European Union's ban on trade in seal products. Environmental Politics, 22(2), 255-273.

World Trade Organization (WTO). (2014). Appellate Body Report, European Communities-Measures Prohibiting the Importation and Marketing of Seal Products, Dispute Settlement, Dispute (WT/ DS400/AB/R, WT/DS401/AB/R). Geneva, Switzerland: World Trade Organization.

\section{About the Author}

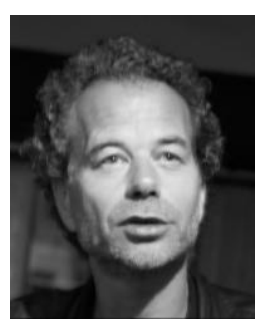

Dr. Lars Christian Blichner

Lars Christian Blichner is Associate Professor at the University of Bergen, Norway. Articles include "The anonymous hand of public reason: Interparliamentary discourse and the quest for legitimacy" (2000), "Political integration in Europe and the need for a common political language" (2007), "Juridification from below: The dynamics of Neil Maccormick's institutional theory of law" (2011), and "Mapping juridification" (with Anders Molander, 2008). 